\title{
Compensatory Elevation of Acetylcholine Synthesis in vivo by Cholinergic Neurons Surviving Partial Lesions of the Septohippocampal Pathway
}

\author{
Paul A. Lapchak, ${ }^{1}$ Donald J. Jenden, ${ }^{2}$ and Franz Hefti ${ }^{1}$ \\ 'Division of Neurogerontology, Andrus Gerontology Center, University of Southern California, Los Angeles, California, \\ 90089 and 'Department of Pharmacology, University of California at Los Angeles, Los Angeles, California 90024
}

The present study characterized the effects of partial destruction of the cholinergic septohippocampal pathway on transmitter functions of surviving cholinergic neurons in the hippocampus. Partial and full fimbrial transections were performed, and 3 weeks after lesioning, cholinergic functions were assessed in vivo and in vitro. Hippocampal ChAT activity and the capacity of hippocampal slices to synthesize [ $\left.{ }^{3} \mathrm{H}\right] \mathrm{ACh}$ in vitro decreased by $35 \%$ and $45 \%$, respectively, following partial fimbrial lesions and by $68 \%$ and $85 \%$, respectively, following full fimbrial lesions. [ $\left.{ }^{3} \mathrm{H}\right] \mathrm{ACh}$ release from hippocampal slices in vitro was decreased by $57 \%$ and $87 \%$, respectively, following partial and full fimbrial lesions. Partial lesions decreased high-affinity choline uptake into hippocampal synaptosomes by $\mathbf{5 2} \%$. In contrast to the significant reductions in cholinergic parameters measured in vitro after partial fimbrial lesions, such partial lesions did not significantly alter in vivo measures of hippocampal cholinergic function. Levels of endogenous $\mathrm{ACh}$ and choline measured in the hippocampus following partial lesions were similar to that of control values. Also, the hippocampal content of newly synthesized $\left[{ }^{2} \mathrm{H}_{4}\right] \mathrm{ACh}$ and the $\left[{ }^{2} \mathrm{H}_{4}\right] \mathrm{ACh}$ synthesis rate were not significantly different from control values. However, following full fimbrial lesions, in vivo measures of hippocampal cholinergic function were decreased to a degree similar to that observed in vitro. Hippocampal levels of endogenous $A C h$ and $\left[{ }^{2} \mathrm{H}_{4}\right] A C h$ and the synthesis rate for $\left[{ }^{2} \mathrm{H}_{4}\right] \mathrm{ACh}$ were decreased by $73 \%, 72 \%$, and $83 \%$, respectively. These results suggest that, following partial destruction of afferent cholinergic fibers that innervate the hippocampal formation, residual cholinergic neurons are able to upregulate their capacity to synthesize and store $\mathrm{ACh}$ in vivo, thus compensating for lesion-induced losses of cholinergic neurons. Residual cholinergic septohippocampal neurons apparently compensate for the loss of neighboring neurons of their population.

\footnotetext{
Received Feb. 15. 1991; revised Apr. 12, 1991; accepted Apr. 17, 1991.

We thank M. Roch, R. Booth, K. M. Rice, and Mr. E. O. Junard for excellent technical assistance. We are grateful to Dr. L. L. Butcher (Los Angeles) for the AChE histochemical procedure and to Dr. B. Knusel, who participated in initial stages of this investigation. This study was supported by U.S. Public Health Service Grants NS22933 and MH17691 and by a grant from the National Parkinson Foundation. P.A.L. was supported by a long-term postdoctoral fellowship from the Human Frontier Science Organization.

Correspondence should be addressed to Dr. P. A. Lapchak, Andrus Gerontology Center, University of Southern California, University Park, MC-0191, Los Angeles, CA 90089.
}

Copyright (C) 1991 Society for Neuroscience $0270-6474 / 91 / 112821-08 \$ 03.00 / 0$
Heterogeneous degenerative changes occurring within neuronal populations are characteristic of brain aging and a variety of neurodegenerative diseases (Bowen et al., 1983; Cross et al., 1984; Candy et al., 1986; D’Amato et al., 1987). Differential degeneration or death of individual neurons results in a residual population of functionally active cells. Upregulation of transmitter-related mechanisms such as the capacity to synthesize, store, and release neurotransmitters may allow residual neuronal populations to compensate partially or fully for the loss of neighboring neurons of the same population. The best-studied example of such compensatory changes by a residual population of neurons is that of dopaminergic neurons forming the nigrostriatal projection, neurons that die progressively in Parkinson's disease (Hornykiewicz, 1972; Bernheimer et al., 1973). Postmortem studies have revealed that dopamine levels in target areas of substantia nigra neurons have to decline to less than $20 \%$ before the clinical manifestation of parkinsonian symptoms (Zigmond and Stricker, 1989; Zigmond et al., 1990). The gradual loss of dopaminergic neurons in Parkinson's disease is mimicked by experimental lesions of rats using 6-hydroxydopamine, a lesion that destroys part of the population of dopaminergic neurons. Such lesions, produced by injecting submaximal amounts of 6-hydroxydopamine into the substantia nigra, result in partial loss of various biochemical parameters reflecting dopaminergic function, and, as found in parkinsonian brains, these partial lesions result in elevations of dopamine synthesis and release by surviving neurons (Agid et al., 1973; Hefti et al., 1980; for reviews, see Zigmond and Stricker, 1989; Zigmond et al., 1990). In addition, there is an increase of the electrical activity of the surviving dopaminergic cells (Zigmond et al., 1990). Five to $10 \%$ of the initial number of dopaminergic neurons seems to be sufficient to provide functional release at the level of a normal nigrostriatal population (Melamed et al., 1981; Stachowiak et al., 1987), suggesting a very high capacity for transmitter synthesis and release by surviving dopaminergic neurons. In addition, following an extensive nigral lesion $(>80 \%)$ dopaminergic neurons remain responsive to pharmacological stimulation and release dopamine at a faster rate (Hefti et al., 1985).

In contrast to these well-established compensatory elevations in dopamine synthesis and release by nigrostriatal neurons, little is known about compensatory increases by residual populations in other neuronal systems. After partial injury to central noradrenergic neuronal systems, the ratio of extracellular norepinephrine, measured by microdialysis, to norepinephrine contained in the tissue is elevated, suggesting compensation in the 
noradrenergic system similar to that in the dopaminergic systems (Abercrombie and Zigmond, 1989). Comparable studies concerning compensatory mechanisms of central cholinergic neurons or other non-catecholaminergic neurons are not available.

Recently, while studying the effects of partial transections of the fimbria, the major afferent pathway of hippocampal cholinergic innervation (Kasa, 1986), we observed in vivo compensatory changes occurring in residual hippocampal cholinergic neurons. This finding was of particular interest considering the wealth of knowledge concerning the role of the hippocampal cholinergic system in memory formation and consolidation and cognitive impairment associated with the degeneration of hippocampal cholinergic neurons (Bartus et al., 1982; Olton and Wenk, 1987). The septohippocampal cholinergic neurons coursing through the fimbria represent part of the ascending cholinergic projections that provide a widespread and topographically organized innervation to the hippocampus and cerebral cortex (Mesulam et al., 1983a,b; Butcher and Woolf, 1986; for review, see Kasa, 1986). These neuronal populations have been shown to be involved in functions related to cognition and memory (for review, see Bartus et al., 1982; Olton and Wenk, 1987). Degenerative changes of these systems, including cell loss, represent characteristic neuropathological and neurochemical fedtures of Alzheimer's disease (Bowen et al., 1976; Davies and Maloney, 1976; Perry et al., 1978; Whitehouse et al., 1982; Arendt et al., 1983; Coyle et al., 1983; Nagai et al., 1983; Francis et al., 1985; Araujo et al., 1988a; Lapchak et al., 1989a; Quirion et al., 1989).

In the present study, we thoroughly investigated the effects of partial and full transections of the fimbria on presynaptic cholinergic function in the hippocampus. A variety of hippocampal cholinergic parameters were measured in vivo and in vitro. These included ChAT activity, in vitro ACh synthesis and release rates, and in vivo ACh synthesis rates. Our results demonstrate compensatory increases of $\mathrm{ACh}$ synthesis in vivo by hippocampal cholinergic neurons surviving a partial lesion of the septohippocampal projection.

\section{Materials and Methods}

Materials. A total of 200 female Wistar rats (185-220 gm) purchased from Charles River Breeding Farms were used for these studies. [Methyl$\left.{ }^{3} \mathrm{H}\right]$ choline chloride $(86.7 \mathrm{Ci} / \mathrm{mmol})$ and $\left[{ }^{3} \mathrm{H}\right]$ acetyl coenzyme $\mathrm{A}$ ( $\left[{ }^{3} \mathrm{H}\right]$ acetyl $\left.\mathrm{CoA} ; 200 \mathrm{mCi} / \mathrm{mmol}\right)$ were obtained from New England Nuclear (Boston, MA). $\left[{ }^{2} \mathrm{H}_{4}\right]$ choline and $\left[{ }^{2} \mathrm{H}_{4}\right] \mathrm{ACh}$ were prepared as described previously (Jenden et al., 1973). Physostigmine sulfate, choline chloride, glycylglycine, dithiothreitol, ATP disodium salt, veratradine hydrochloride, choline kinase (EC 2.7.1.32, ATP: choline phosphotransferase), acetylcholine esterase (EC 3.1.1.7, acetylcholine hydrolase, type V-S), 3-heptanone, and tetraphenylboron (TPB) sodium salt were from Sigma Chemical Co. (St. Louis, MO).

Lesions. Fimbrial lesions were performed as described previously by Lapchak and Hcfti (1991). Bricfly, rats were anesthetized with equitensin (pentobarbital) and placed in a stereotaxic apparatus. A small slit was cut into the skull on the left side and $2.0 \mathrm{~mm}$ posterior to bregma. For full transections of the fimbria-fornix connection between septum and hippocampus, a lancet-shaped knife $(8 \mathrm{~mm}$ long, $0.7 \mathrm{~mm}$ wide, with a sharp tip) was lowered $5 \mathrm{~mm}$ below the dura in to the brain at the midline and at $2.0 \mathrm{~mm}$ posterior to bregma (corresponding to level A6100 according to the atlas of Koenig and Klippel, 1963). The knife was then moved laterally to $5.0 \mathrm{~mm}$ lateral to the midline and retrieved at this position. For partial transections of the fimbria-fornix connection between septum and hippocampus, the knife was inserted $5 \mathrm{~mm}$ below the dura into the brain $1.5 \mathrm{~mm}$ lateral to the midline and at the same anteroposterior position. The knife was also moved laterally to $5.0 \mathrm{~mm}$ lateral to the midline and retrieved at this position. The areas transected

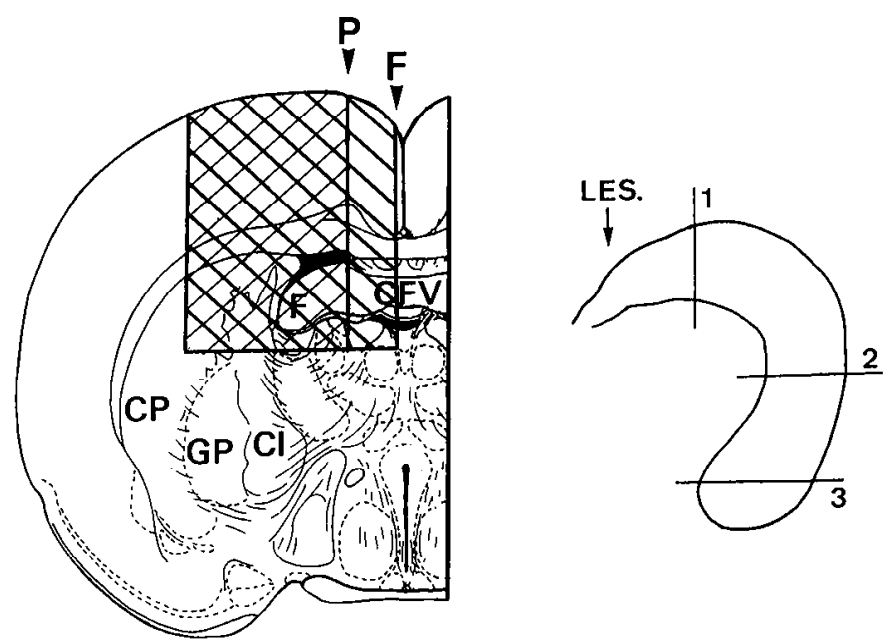

Figure 1. Full and partial transection of the fimbria-fornix as performed in the present study. A lancet-shaped knife was inserted at the midline or $1.5 \mathrm{~mm}$ lateral to the midline and then moved laterally. Because of the elasticity of the fimbria, and to ensure its transection, the knife was moved farther lateral $(0.20 \mathrm{~mm})$ than the fimbria's normal position. The cross hatched area is cut by both types of lesions; the hatched area, by the full transection only. $F$, position of knife insertion for full fimbrial transections; $P$, initial position of knife for partial transections. Anatomical structures: $C F V$, ventral commisure of fornix; $C I$ internal capsule; $C P$, caudate putamen; $F$, fimbria; $G P$, globus pallidus The lesions were verified using AChE as a marker for hippocampal cholinergic axons. The drawing on the right shows the localization of sections taken for AChE histochemistry and shown in Figure 2.

by the two types of lesions are illustrated in Figure 1. All animals were used 3 weeks following partial or full fimbrial transections, based on earlier studies indicating completion of degenerative changes after that interval of time (Hefti et al., 1984; Montero and Hefti, 1988).

Measurement of $\left.{ }^{3} \mathrm{H}\right] A C h$ synthesis in tissue slices. Brain slices were prepared as previously described by Lapchak and Collier (1988) and Lapchak and Hefti (1991). Briefly, the animals were decapitated, and the brains were rapidly removed into cold Krebs' medium (composition, in mM: $\mathrm{NaCl}, 120 ; \mathrm{KCl}, 4.6 ; \mathrm{CaCl}_{2}, 2.4 ; \mathrm{KH}_{2} \mathrm{PO}_{4}, 1.2 ; \mathrm{MgSO}_{4}, 1.2$; glucose, $9.9 ; \mathrm{NaHCO}_{3}, 25$ ) equilibrated with $5 \% \mathrm{CO}_{2}$ in $\mathrm{O}_{2}$ to maintain a $\mathrm{pH}$ of 7.4 at $37^{\circ} \mathrm{C}$. The hippocampus was then dissected on ice and sliced using a McIlwain tissue chopper (set at $0.2 \mathrm{~mm}$ thickness). Slices were preincubated in normal Krebs' medium $(0.50 \mathrm{ml})$ containing physostigmine sulfate $(30 \mu \mathrm{M})$ and choline chloride $(1 \mu \mathrm{M})$ for a recovery period of $45 \mathrm{~min}$, with one change of medium after $30 \mathrm{~min}$. The medium was separated from tissue slices by centrifugation in a microcentrifuge $(10,000 \times g)$. Following this, slices were incubated for $15 \mathrm{~min}$ in normal Krebs' medium in the presence of $2 \mu \mathrm{Ci}\left[{ }^{3} \mathrm{H}\right.$ ]choline chloride (final concentration, $1 \mu \mathrm{M}$ choline chloride). The medium was then separated from the tissue by centrifugation, and the total amount of $\left[{ }^{3} \mathrm{H}\right] \mathrm{ACh}$ contained in the tissue was measured following extraction of the tissue with $10 \%$ trichloroacetic acid (TCA). The sample was centrifuged to remove TCA-insoluble matter, and the resulting supernatant was extracted with $30 \mathrm{vol}$ of water-saturated ether to remove TCA. The aqueous extract was used for the measure of $\left[{ }^{3} \mathrm{H}\right] \mathrm{ACh} .\left[{ }^{3} \mathrm{H}\right] \mathrm{ACh}$ and $\left[{ }^{3} \mathrm{H}\right]$ choline were extracted from the medium by TPB in heptanone $(10 \mathrm{mg} / \mathrm{ml})$ and recovered from the organic phase by shaking with a half volume of $\mathrm{AgNO}_{3}(20 \mathrm{mg} / \mathrm{ml})$. Excess silver was precipitated by the addition of $10 \mu \mathrm{l}$ of $\mathrm{MgCl}_{2}(1 \mathrm{M})$ per $100 \mu \mathrm{l}$ of sample. Samples were then lyophilized, and $\left.{ }^{3} \mathrm{H}\right] \mathrm{ACh}$ was separated from $\left[{ }^{3} \mathrm{H}\right]$ choline by incubation in the presence of choline kinase $(0.005 \mathrm{U})$, in the following reaction mix: ATP $(0.8 \mathrm{~mm})$, dithiothreitol ( $5 \mathrm{~mm}), \mathrm{MgCl}_{2}(12.5 \mathrm{~mm})$, and glycylglycine (25 $\mathrm{mm}, \mathrm{pH} 8.3$ ). After this incubation, which generated $\left[{ }^{3} \mathrm{H}\right]$ phosphorylcholine from $\left[{ }^{3} \mathrm{H}\right]$ choline, leaving the $\left[{ }^{3} \mathrm{H}\right] \mathrm{ACh}$ unchanged, the $\left[{ }^{3} \mathrm{H}\right] \mathrm{ACh}$ was extracted by TPB/heptanone $(10 \mathrm{mg} / \mathrm{ml})$. For each sample, an assay blank was prepared by treating an aliquot of each sample with AChE before incubation with choline kinase, which allowed for the correction of any contribution that would be made by $\left[{ }^{3} \mathrm{H}\right]$ choline in the samples. The $\left[{ }^{3} \mathrm{H}\right] \mathrm{ACh}$ was quantitated by liquid scintillation spectrometry using 
The Journal of Neuroscience, September 1991, 11(9) 2823
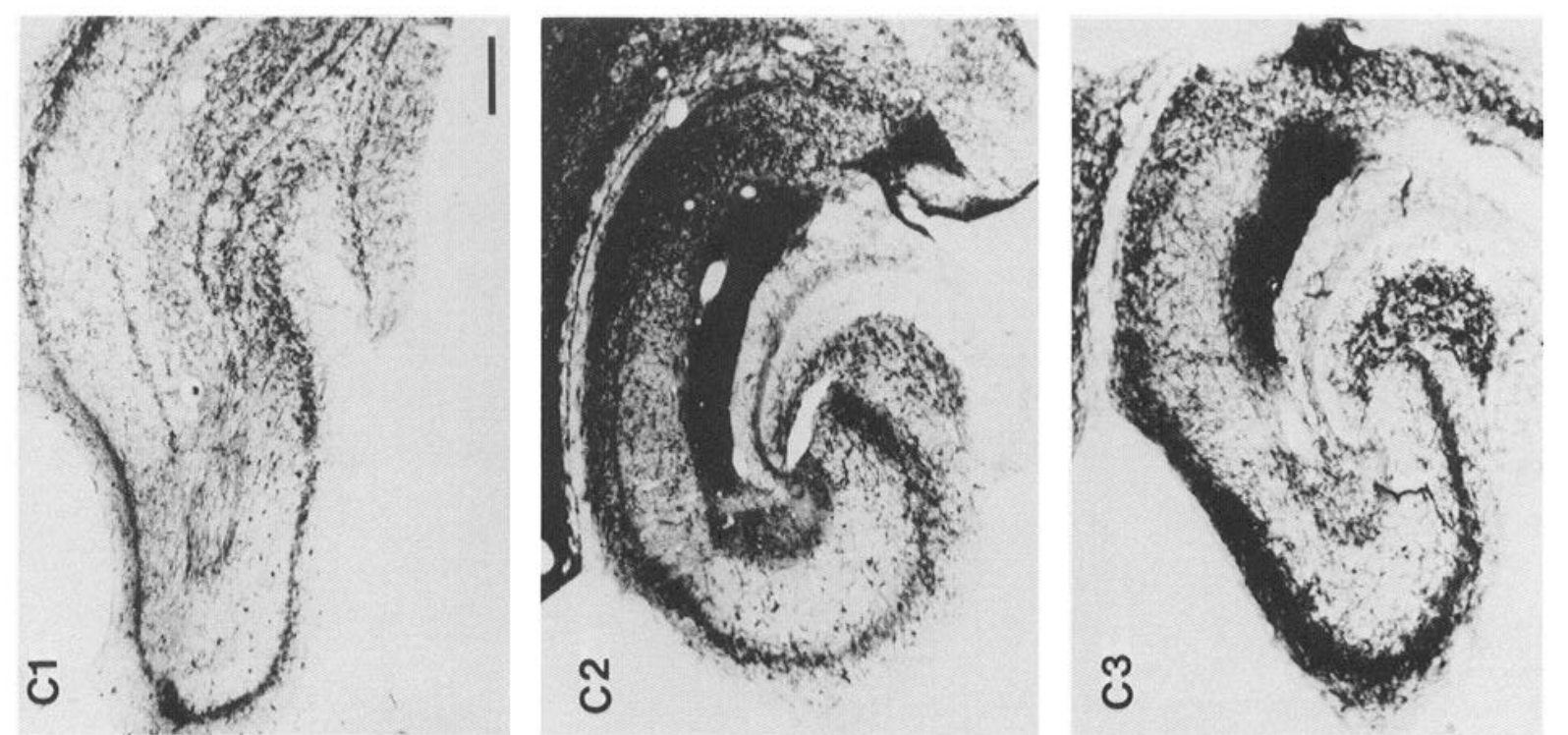

起获
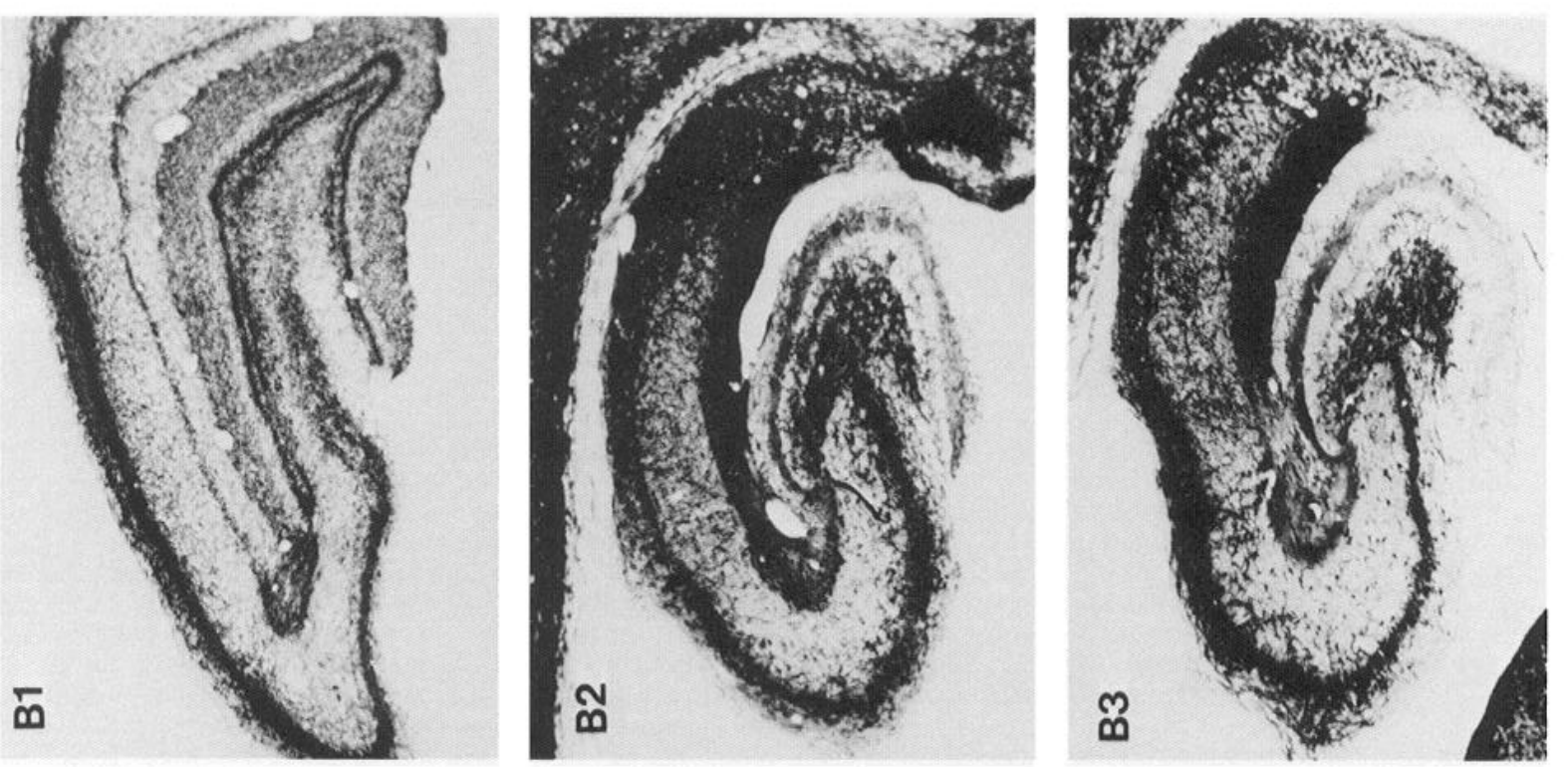

东

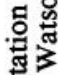

害完

论

A.

证

过卷需

进

엉

폄. 옹

명항

灵嵒

ㄴㅇㅇㅡ.

ชำ

沓

, 号.

명

흥저

훙ㅎㅇㅇㅇㅇ

동

ड़्ठ̀n

สื ปี

들.

흥?

ํㅜㅇ

형
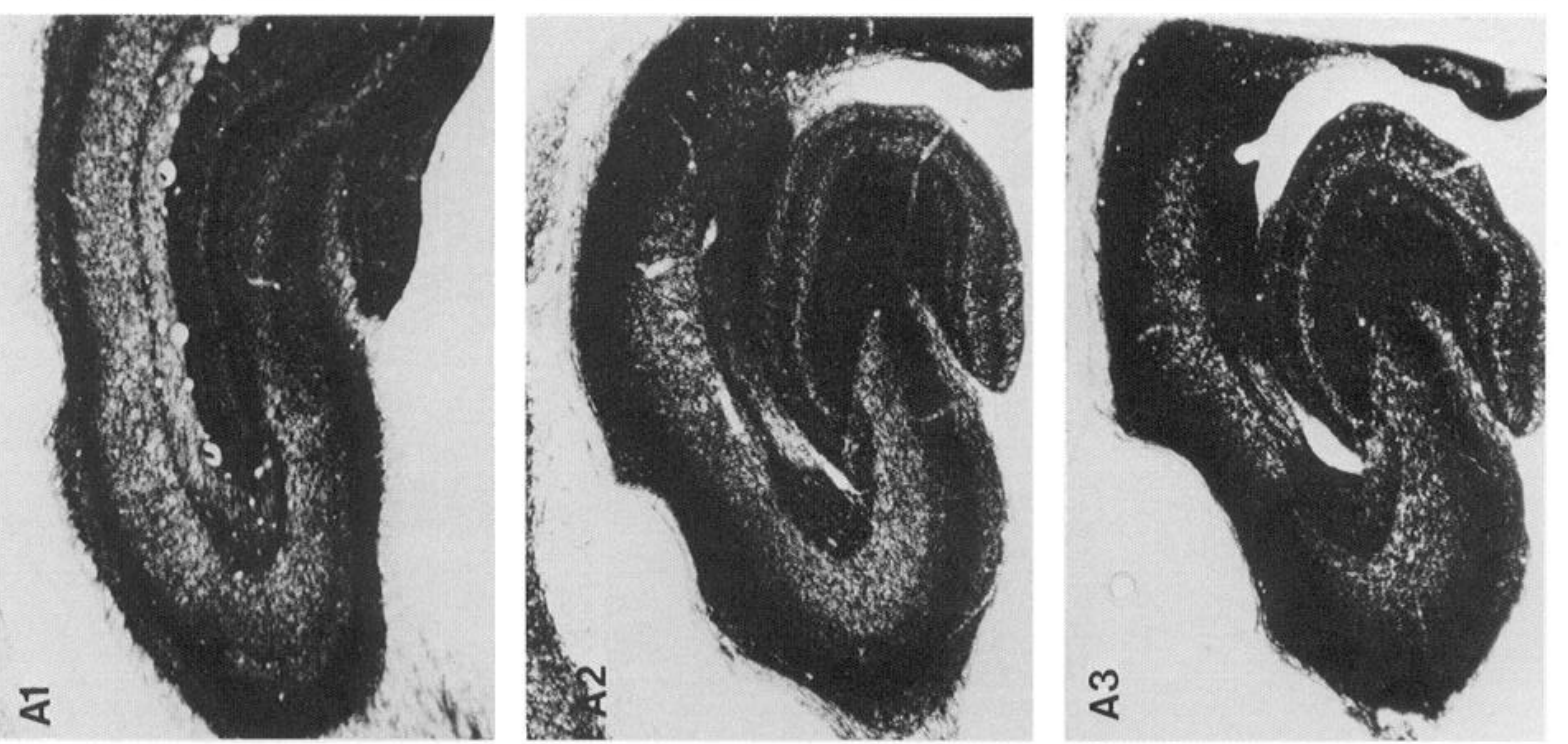

동요 믐

을

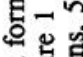

즘

్ㅐㅇㅛ

연

월

जon

s 1 if

晋递

ऽ

हैं

品

녕영

ชี

녕으

남

马ै

要

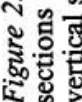


Figure 3. Upregulation of ACh synthesis in vivo after partial fimbrial transections. The figure indicates values of parameters reflecting cholinergic function in vitro or in vivo in lesioned hippocampus as percentage of the values measured on the unlesioned control sides (means \pm SEM). $A$, ChAT activity in hippocampal homogenates; $B,\left[{ }^{3} \mathrm{H}\right]$ ACh synthesis by hippocampal slices in vitro; $C .\left[{ }^{3} \mathrm{H}\right] \mathrm{ACh}$ release by hippocampal slices in vitro; $D$, HACU by hippocampal synaptosomes; $E$, hippocampal ACh content in vivo; $F$, hippocampal $\left[{ }^{2} \mathrm{H}_{4}\right] \mathrm{ACh}$ content in vivo; $G$, hippocampal ACh synthesis rate in vivo $\left(\left[{ }^{2} \mathrm{H}_{4}\right] \mathrm{ACh} \times\right.$ total choline $/\left[{ }^{2} \mathrm{H}_{4}\right]$ choline). Significance versus corresponding controls, ${ }^{* * *} p<0.001,{ }^{* *} p$ $<0.01,{ }^{*} p<0.05$.

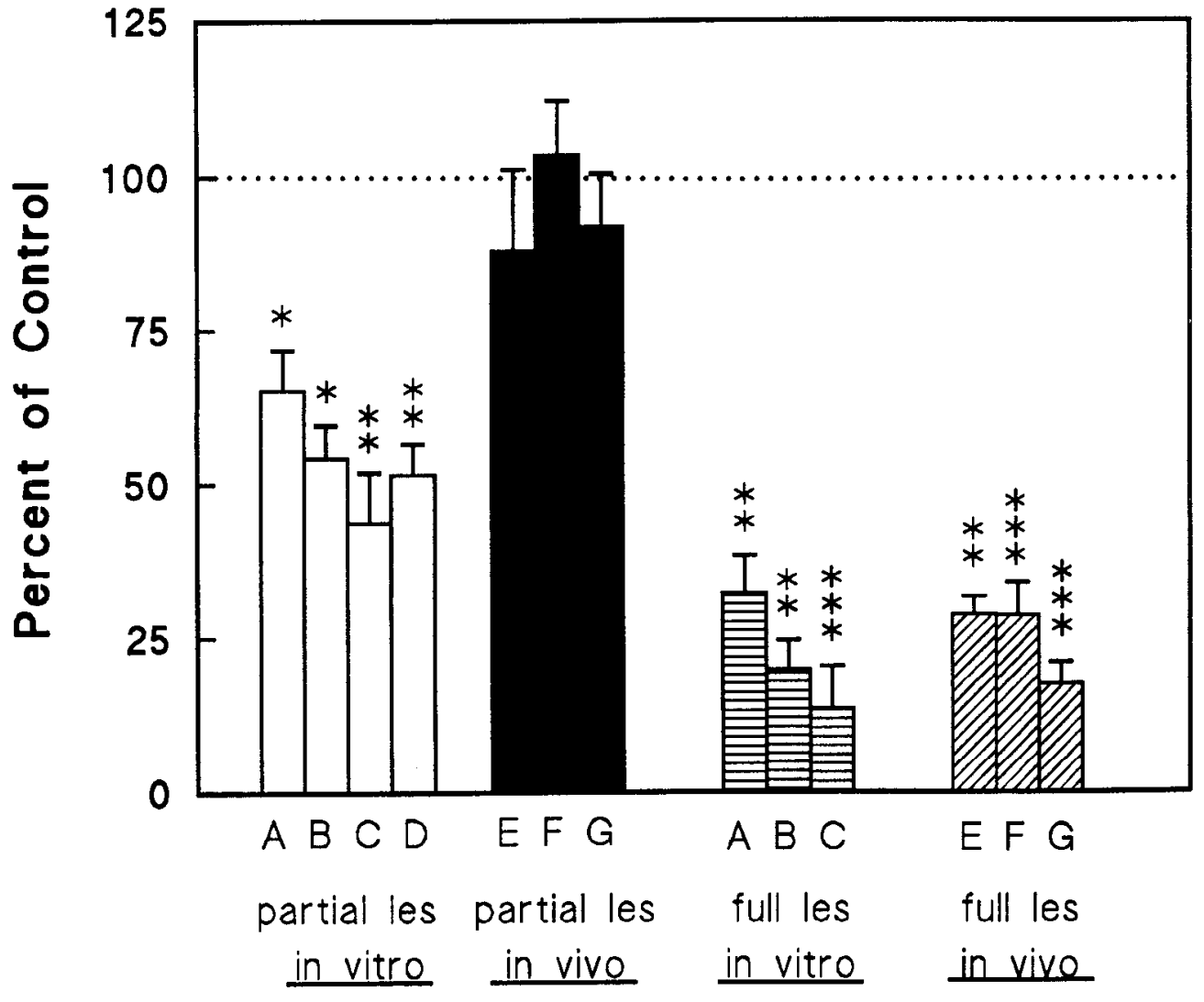

Optiphase 'HISAFE' 3 (LKB Laboratories) as solvent. In a series of experiments, the release of newly synthesized [ $\left.{ }^{3} \mathrm{H}\right] \mathrm{ACh}$ from hippocampal slices was measured in vitro as described previously by Lapchak and Collier (1988). For this, hippocampal slices were incubated in Krebs' medium for 15 min following the synthesis period described above. Following the incubation, tissuc slices were pelleted by microcentrifugation, and the amount of $\left[{ }^{3} \mathrm{H}\right] \mathrm{ACh}$ in the supernatant was measured. A second incubation was carried out in the presence of the depolarizing agent veratridine in order to evoke $\left[{ }^{3} \mathrm{H}\right] \mathrm{ACh}$ release. The sum of the values was used as total $\left[{ }^{3} \mathrm{H}\right] \mathrm{ACh}$ output following partial or full fimbrial lesions.

Assay for ChAT activity. ChAT activity was determined as described previously by Araujo et al. (1988a) and Lapchak and Hefti (1991). Tissue was homogenized in a medium of the following composition: $\mathrm{NaCl}(200$ $\mathrm{mm})$, sodium phosphate buffer ( $\mathrm{pH}, 7.4 ; 40 \mathrm{~mm})$, and Triton $\mathrm{X}-100$ $(0.5 \%)$. Samples $(35 \mu \mathrm{l})$ were then incubated $\left(38^{\circ} \mathrm{C}, 30 \mathrm{~min}\right)$ in a medium $(15 \mu 1)$ containing unlabeled acetyl $\mathrm{CoA}$ and $\left[{ }^{3} \mathrm{H}\right]$ acetyl $\mathrm{CoA}(50,000-$ $60,000 \mathrm{dpm}$ per tube; final concentration, $0.25 \mathrm{~mm}$ acetyl $\mathrm{CoA}$ ), choline chloride (12.5 mM), physostigmine sulfate $(0.2 \mathrm{mM}), \mathrm{NaCl}(300 \mathrm{~mm})$,

Table 1. ChAT activity in hippocampal homogenates of rats with partial or full fimbrial transections

\begin{tabular}{lllll} 
& & \multicolumn{3}{l}{ ChAT activity $(\mathrm{nmol} / \mathrm{mg}$ protein/hr) } \\
\cline { 2 - 5 } & $n$ & $\begin{array}{l}\text { Lesioned } \\
\text { side }\end{array}$ & $\begin{array}{l}\text { Unlesioned } \\
\text { side }\end{array}$ & \multicolumn{1}{l}{$\begin{array}{l}\text { Percent } \\
\text { control }\end{array}$} \\
\hline Unlesioned control & 10 & $48.4 \pm 2.9$ & $50.4 \pm 3.3$ & $107.9 \pm 3.4$ \\
Partial transections & 10 & $31.4 \pm 4.0^{*}$ & $47.8 \pm 3.9$ & $65.2 \pm 6.6$ \\
Full transections & 10 & $15.9 \pm 4.4^{* *}$ & $54.4 \pm 2.6$ & $32.2 \pm 6.2$
\end{tabular}

Values represent the means \pm SEM of the number of experiments indicated under $n$. Enzyme activities from lesioned animals are significantly different from contralateral control values $\left(* p<0.05,{ }^{* *} p<0.01\right)$. Percent control values indicate values obtained on the lesioned side divided by that obtained on the unlesioned control side.
Na-phosphate buffer ( $\mathrm{pH}, 7.4 ; 28 \mathrm{~mm})$, bovine serum albumin $(0.5 \mathrm{mg}$ $\mathrm{ml})$, and Triton $\mathrm{X}-100(0.35 \%)$. The reaction was terminated by the addition of TPB/heptanone $(15 \mathrm{mg} / \mathrm{ml})$, which extracts the $\left[{ }^{3} \mathrm{H}\right] \mathrm{ACh}$ but not the $\left[{ }^{3} \mathrm{H}\right]$ acetyl $\mathrm{CoA}$. Radioactivity in the top organic phase was determined by liquid scintillation spectrometry.

High-affinity choline uptake (HACU) in hippocampal synaptosomes. The hippocampus was dissected and homogenized in $0.32 \mathrm{M}$ sucrose. Synaptosomes (P2 pellet) were prepared as described previously by Lapchak and Collier (1988). An aliquot of the synaptosomal suspension was incubated with $40 \mathrm{~nm}\left[{ }^{3} \mathrm{H}\right]$ choline $(8 \mathrm{Ci} / \mathrm{mmol})$ for $4 \mathrm{~min}$. The uptake was terminated by filtration through glass-fiber filters. Nonspecific uptake was defined as uptake occurring at $4^{\circ} \mathrm{C}$, which is identical to that measured in the presence of $10 \mu \mathrm{M}$ unlabeled HC-3. Radioactivity bound to the filters was measured using liquid scintillation spectrometry following solubilization of the filters.

Measurement of ACh synthesis in vivo. Rats were injected with $\left[{ }^{2} \mathrm{H}_{4}\right]$ choline $(20 \mathrm{nmol} / \mathrm{gm})$ via the tail vein and killed $1 \mathrm{~min}$ later by focused microwave irradiation of the head $(5 \mathrm{~kW}$ for $1.7 \mathrm{sec})$. Brains were then removed, the hippocampus was dissected, and $\mathrm{ACh}$ and cho-

Table 2. [ $\left.{ }^{3} \mathrm{H}\right] \mathrm{ACh}$ synthesis from $\left[{ }^{3} \mathrm{H}\right]$ choline by hippocampal slices from rats with partial or full fimbrial transections

$\left[{ }^{3} \mathrm{H}\right] \mathrm{ACh}$ synthesis (dpm ACh formed $/ \mathrm{mg}$ wet weight $/ 15 \mathrm{~min}$ )

$n$\begin{tabular}{lll}
\hline $\begin{array}{l}\text { Lesioned } \\
\text { side }\end{array}$ & $\begin{array}{l}\text { Unlesioned } \\
\text { side }\end{array}$ & $\begin{array}{l}\text { Percent } \\
\text { control }\end{array}$ \\
\hline
\end{tabular}

Unlesioned control $102879.9 \pm 137.6 \quad 2604.3 \pm 193.799 .7 \pm 8.6 \%$ Partial transections $101385.2 \pm 144.2^{*} 2489.0 \pm 67.5 \quad 54.3 \pm 5.4 \%$ Full transections $10 \quad 479.3 \pm 72.9^{* *} 3144.2 \pm 319.019 .7 \pm 4.9 \%$

This table shows the effect of fimbrial lesions on $\left[{ }^{3} \mathrm{H}\right] \mathrm{ACh}$ synthesis by hippocampal slices incubated in the presence of the precursor molecule $\left[{ }^{3} \mathrm{H}\right]$ choline. Values represent the means + SEM of the number of experiments given under $n$. Partial and full fimbrial transections reduced the synthesis of $\left[{ }^{3} \mathrm{H}\right] \mathrm{ACh}$ by hippocampal slices. Significance versus contralateral control values: ${ }^{*} p<0.05,{ }^{* *} p<0.01$. 


\begin{tabular}{|c|c|c|c|c|}
\hline & \multirow[b]{2}{*}{$n$} & \multicolumn{3}{|c|}{$\begin{array}{l}\text { ACh and choline concentration } \\
\text { (nmol/gm wet weight) }\end{array}$} \\
\hline & & $\begin{array}{l}\text { Lesioned } \\
\text { side }\end{array}$ & $\begin{array}{l}\text { Unlesioned } \\
\text { side }\end{array}$ & $\begin{array}{l}\text { Percent } \\
\text { control }\end{array}$ \\
\hline \multicolumn{5}{|c|}{ Unlesioned control } \\
\hline $\mathrm{ACh}$ & 10 & $35.40 \pm 2.65$ & $35.00 \pm 0.75$ & $100.7 \pm 6.5$ \\
\hline Choline & 10 & $61.53 \pm 6.70$ & $57.34 \pm 3.50$ & $111.9 \pm 10.4$ \\
\hline \multicolumn{5}{|c|}{ Partial transection } \\
\hline $\mathrm{ACh}$ & 12 & $31.63 \pm 2.10$ & $37.92 \pm 2.35$ & $88.0 \pm 13.1$ \\
\hline Choline & 12 & $63.38 \pm 9.41$ & $55.36 \pm 5.79$ & $99.7 \pm 12.7$ \\
\hline \multicolumn{5}{|c|}{ Full transection } \\
\hline $\mathrm{ACh}$ & 14 & $10.85 \pm 1.72^{* *}$ & $32.07 \pm 1.02$ & $28.7 \pm 2.9$ \\
\hline Choline & 14 & $59.12 \pm 5.48$ & $59.65 \pm 4.90$ & $95.5 \pm 7.4$ \\
\hline
\end{tabular}

Animals were killed by focused microwave irradiation of the brain. Values are expressed as nmol/gm wet weight and are the means \pm SEM of the number of determinations shown under $n$. Full fimbrial transection significantly decreased the levels of $\mathrm{ACh}$ in the hippocampal formation. Significance versus corresponding control side: ${ }^{* *} p<0.01$.

line were extracted as ion pairs with dipicrylamine (Freeman et al., 1981). Their concentrations were then measured by gas chromatography-mass spectrometry (GCMS; Jenden et al., 1973). Rates of ACh synthesis were calculated as described previously by Jenden et al. (1974).

Acetylcholinesterase (AChE) histochemistry. Adult rats were deeply anesthetized with equitensin and perfused transaortically as described previously by Lapchak et al. (1991). Briefly, animals were perfused with a mixture of $4 \%$ paraformaldehyde and $0.2 \%$ picric acid in $0.1 \mathrm{M}$ phosphate buffer ( $\mathrm{pH} 7.4$ ). The brain was removed from the skull, postfixed overnight in the same solution, and immersed overnight in a $30 \%$ sucrose phosphate-buffered solution. They were snap frozen by immersion in 2-methylbutane at $-40^{\circ} \mathrm{C}$, and $30 \mu \mathrm{m}$ sections were cut on a cryostat. $\mathrm{AChE}$ was visualized according to Tago et al. (1986). Floating sections were preincubated for $30 \mathrm{~min}$ at room temperature with $30 \mu \mathrm{M}$ tetraisopropyl pyrophosphoramide (iso-OMPA) to inhibit nonspecific cholinesterases. They were then incubated for $15 \mathrm{~min}$ at room temperature in a solution of $0.5 \mathrm{mg} / \mathrm{ml}$ acetylthiocholine iodide, $3 \mathrm{mM} \mathrm{CuSO}_{4}, 0.5$ $\mathrm{mM} \mathrm{K}_{3} \mathrm{Fe}(\mathrm{CN})_{6}$, and $5 \mathrm{~mm}$ sodium citrate in $0.1 \mathrm{M}$ Tris-maleate buffer $(\mathrm{pH}, 5.7)$, and diluted $1: 10$ with $0.1 \mathrm{M}$ sodium phosphate buffer $(\mathrm{pH}, 7.2)$ immediately before use. After incubation, the sections were washed, and the reaction product was visualized by incubating them in a solution containing 4\% diaminobenzidine, $0.3 \%$ nickel ammonium sulfate, and $0.003 \% \mathrm{H}_{2} \mathrm{O}_{\text {. }}$.

Statistical analyses. Data points given correspond to values from hippocampus of individual animals. Results are typically expressed as means \pm SEM of the number of experiments or animals, as indicated. Statistical significance was assessed using analysis of variance (ANOVA) followed by the Student's unpaired $t$ test and Scheffé's test.

\section{Results}

Partial and full fimbrial transections were used to produce, respectively, partial or near-total reductions of the cholinergic input to the hippocampus. As described in detail in an earlier study (Hefti et al., 1984), 3 weeks following partial fimbrial transections there was a reduction in the density of AChE-positive fibers throughout the hippocampal formation of the lesioned side (Fig. 2). There was a gradual decrease in density of AChE fibers throughout the hippocampal formation. Overall, a progressive reduction in the intensity of $\mathrm{AChE}$ staining was observed proceeding from the scptal to the temporal polc of the hippocampus. Near the septal pole, the reductions in the CA3 area were more pronounced than those in the dentate gyrus. Full fimbrial transections significantly reduced AChE staining throughout the hippocampal formation, leaving only a small number of residual fibers in dentate gyrus and the CA3 region (Fig. 2).
ChAT activity in hippocampal homogenates and $\left[{ }^{3} \mathrm{H}\right] \mathrm{ACh}$ synthesis by hippocampal slices were measured to assess presynaptic cholincrgic function in vitro. Partial and full fimbrial transections reduced ChAT activity on the lesioned side to $65.0 \%$ and $32.2 \%$, respectively, of values measured on unlesioned control sides (Table 1). There were no significant changes in unlesioned hippocampus as compared to nonlesioned control animals (94-108\% of control), justifying the use of the unlesioned sides as controls. Similar reductions were obtained when measuring [ $\left.{ }^{3} \mathrm{H}\right] \mathrm{ACh}$ synthesis by hippocampal slices. $\left[{ }^{3} \mathrm{H}\right] \mathrm{ACh}$ synthesis from the precursor molecule $\left[{ }^{3} \mathrm{H}\right]$ choline was reduced to $54.3 \%$ and $19.7 \%$ of control values in hippocampus with partial and full fimbrial transections, respectively (Table 2). As described above for ChAT activity, unilateral fimbrial lesions did not result in significant changes of $\left[{ }^{3} \mathrm{H}\right] \mathrm{ACh}$ synthesis on the unlesioned sides (95-120\% of control). $\left[{ }^{3} \mathrm{H}\right] \mathrm{ACh}$ release from hippocampal slices in vitro was also significantly decreased by both partial and full fimbrial lesions (Fig. 3). These values were $43.7 \pm 8.2 \%$ and $13.5 \pm 6.8 \%$ of control values for partial and full fimbrial lesions, respectively.

High affinity choline uptake (HACU), rather than ChAT activity, is generally believed to be the rate-limiting step in ACh synthesis in vivo (Jope, 1979; Collier, 1988). Therefore, we measured choline uptake into hippocampal synaptosomes prepared from animals with partial fimbrial lesions to obtain a fourth in vitro parameter reflecting presynaptic cholinergic function. Similar to the findings obtained with ChAT activity and $\left[{ }^{3} \mathrm{H}\right] \mathrm{ACh}$ synthesis (see above), HACU was reduced following partial fimbrial lesions. Choline uptake on the control unlesioned side was $4.85 \pm 0.24 \mathrm{pmol} / \mathrm{mg}$ protein $/ 4 \mathrm{~min}$, whereas on the lesioned side choline uptake was $2.95 \pm 0.20 \mathrm{pmol} / \mathrm{mg}$ protein $/ 4 \mathrm{~min}$ $(n=9)$. Accordingly, the partial fimbrial lesion reduced choline uptake to $51.6 \pm 4.9 \%$ of unlesioned control values.

The pronounced reductions in presynaptic cholinergic function observed with three different in vitro methods after partial lesions of the fimbria were compared with changes in levels of endogenous choline and $\mathrm{ACh}$, as well as the synthesis of $\left[{ }^{2} \mathrm{H}_{4}\right] \mathrm{ACh}$ from $\left[{ }^{2} \mathrm{H}_{4}\right]$ choline in vivo. Levels of endogenous choline in the hippocampus were not altered by partial or full fimbrial transections (Table 3). Both types of lesions left the levels of endogenous $\mathrm{ACh}$ unchanged on unlesioned control sides. Partial 
Table 4. Synthesis of $\left[{ }^{2} \mathrm{II}_{4}\right] \mathrm{ACh}$ synthesis from systemically injected $\left[{ }^{2} \mathrm{H}_{4}\right]$ choline in hippocampus of rats with partial or complete fimbrial transections

\begin{tabular}{|c|c|c|c|c|}
\hline & \multirow[b]{2}{*}{$n$} & \multicolumn{3}{|c|}{$\begin{array}{l}\text { Hippocampal }\left[{ }^{2} \mathrm{H}_{4}\right] \mathrm{ACh} \text { and }\left[{ }^{2} \mathrm{H}_{4}\right] \text { choline } \\
\text { concentration (nmol/gm wet weight) }\end{array}$} \\
\hline & & Lesioned side & Unlesioned side & Percent control \\
\hline \multicolumn{5}{|c|}{ Unlesioned controls } \\
\hline $\mathrm{ACh}$ & 9 & $0.52 \pm 0.05$ & $0.58 \pm 0.05$ & $110.1 \pm 7.5$ \\
\hline Choline & 9 & $2.01 \pm 0.22$ & $1.93 \pm 0.25$ & $90.3 \pm 17.7$ \\
\hline \multicolumn{5}{|c|}{ Partial transections } \\
\hline $\mathrm{ACh}$ & 12 & $0.55 \pm 0.11$ & $0.56 \pm 0.11$ & $103.5 \pm 8.7$ \\
\hline Choline & 12 & $1.83 \pm 0.39$ & $2.02 \pm 0.49$ & $109.1 \pm 10.1$ \\
\hline \multicolumn{5}{|c|}{ Full transections } \\
\hline $\mathrm{ACh}$ & 14 & $0.15 \pm 0.04^{* * *}$ & $0.53 \pm 0.03$ & $28.5 \pm 5.3$ \\
\hline Choline & 14 & $2.54 \pm 0.14$ & $2.10 \pm 0.14$ & $84.5 \pm 5.8$ \\
\hline
\end{tabular}

Data were obtained from same animals and tissues as those shown in Table 3 . Animals were injected intravenously with $\left[{ }^{2} \mathrm{H}_{4}\right]$ choline $1 \mathrm{~min}$ prior to death by focused microwave irradiation. Tissue levels of $\left[{ }^{2} \mathrm{H}_{4}\right] \mathrm{ACh}$ and $\left[{ }^{2} \mathrm{H}_{4}\right] \mathrm{choline}$ were then determined by GCMS. Full fimbrial transections reduced the tissue levels of $\left[{ }^{2} \mathrm{H}_{4}\right]$ ACh. All other values are not statistically different from contralateral control values. Significance versus corresponding control side: ${ }^{* * *} \rho<0.001$.

fimbrial transections reduced endogenous $\mathrm{ACh}$ levels on the lesioned side only to $88.0 \pm 13.1 \%$ of the level on the corresponding unlesioned side; however, this small reduction did not reach statistical significance $(p>0.05)$. Following full fimbrial transections, the levels of endogenous $\mathrm{ACh}$ werc reduced to 28.7 $\pm 2.9 \%$ of control values (Table 3 ).

While often used as an indicator for dynamic changes in $\mathrm{ACh}$ metabolism, ACh levels do not provide an accurate reflection of ACh synthesis in vivo. A better estimate of in vivo ACh synthesis is obtained by measuring the concentration of $\left[{ }^{2} \mathrm{H}_{4}\right] \mathrm{ACh}$ in the hippocampus formed following systemically administered $\left[{ }^{2} \mathrm{H}_{4}\right]$ choline. Furthermore, this experimental approach allows for the calculation of a synthesis rate for $\left[{ }^{2} \mathrm{H}_{4}\right] \mathrm{ACh}$ by hippocampal neurons in vivo (Jenden et al., 1974). The synthesis rate of $\left[{ }^{2} \mathrm{H}_{4}\right] \mathrm{ACh}$ represents the product of $\left[{ }^{2} \mathrm{H}_{4}\right] \mathrm{ACh}$ and total choline/ $\left[{ }^{2} \mathrm{H}_{4}\right]$ choline and corrects for eventual changes in $\left[{ }^{2} \mathrm{H}_{4}\right]$ choline availability. Values representative of in vivo $\left[{ }^{2} \mathrm{H}_{4}\right] \mathrm{ACh}$ synthesis rates are provided in Table 4 . Partial fimbrial lesions did not reduce the levels of $\left[{ }^{2} \mathrm{H}_{4}\right] \mathrm{ACh}$ synthesized from $\left[{ }^{2} \mathrm{H}_{4}\right]$ choline or the rate of $\left[{ }^{2} \mathrm{H}_{4}\right] \mathrm{ACh}$ turnover by hippocampal cholinergic neurons; values on lesioned sides were $103.5 \perp 8.7 \%$ and $109.1 \pm$ $8.5 \%$, respectively, of the values obtained on the corresponding unlesioned side.

In contrast to the absence of change of these cholinergic parameters in vivo following partial lesions, complete fimbrial transections resulted in pronounced reductions of several cholinergic parameters. Endogenous ACh levels, levels of $\left[{ }^{2} \mathrm{H}_{4}\right] \mathrm{ACh}$ formed

Table 5. Synthesis rate of $\mathrm{ACh}$ in hippocampus of rats with partial or full fimbrial transections

\begin{tabular}{lllll} 
& \multicolumn{2}{l}{ ACh synthesis rate } \\
\cline { 2 - 5 } & $n$ & $\begin{array}{l}\text { Lesioned } \\
\text { side }\end{array}$ & $\begin{array}{l}\text { Unlesioned } \\
\text { side }\end{array}$ & $\begin{array}{l}\text { Percent } \\
\text { control }\end{array}$ \\
\hline Unlesioned control & 10 & $17.14 \pm 2.49$ & $19.04 \pm 1.92$ & $98.7 \pm 6.8$ \\
Partial transection & 12 & $18.09 \pm 3.50$ & $20.56 \pm 5.31$ & $91.9 \pm 8.5$ \\
Full transection & 14 & $4.82 \pm 0.88^{* * *}$ & $27.68 \pm 2.06$ & $17.4 \pm 3.5$
\end{tabular}

ACh synthesis rates, defined as $\left[{ }^{2} \mathrm{H}_{4}\right] \mathrm{ACh} \times$ total choline $/\left[{ }^{2} \mathrm{H}_{4}\right]$ choline, were calculated from the data listed in Tables 3 and 4 . Significance versus corresponding control side: $* * * p<0.001$. from $\left[{ }^{2} \mathrm{H}_{4}\right]$ choline, and the rate of $\left[{ }^{2} \mathrm{H}_{4}\right]$ ACh synthesis by hippocampal neurons following full fimbrial lesions were reduced to $28.7 \pm 2.9 \%, 28.5 \pm 5.3 \%$, and $17.4 \pm 3.5 \%$, respectively, of control values from the unlesioned side (Table 5). These decrements are similar to those obtained when measuring the in vitro parameters described above. These findings suggest that functional compensation does not occur in the cholinergic terminals surviving full fimbrial transections.

The compensatory increases in ACh synthesis by cholinergic axons surviving partial fimbrial transections are further illustrated in Figure 3. Partial fimbrial lesions reduced in vitro parameters of presynaptic cholinergic function. ChAT activity, $\left[{ }^{3} \mathrm{H}\right] \mathrm{ACh}$ synthesis and release, and $\mathrm{HACU}$ were decreased by $35-50 \%$. However, in contrast, there were no significant reductions in parameters reflecting cholinergic function in vivo, that is, levels of endogenous $\mathrm{ACh},\left[{ }^{2} \mathrm{H}_{4}\right] \mathrm{ACh}$ synthesis from $\left[{ }^{2} \mathrm{H}_{4}\right]$ choline, and the synthesis rate of $\left[{ }^{2} \mathrm{H}_{4}\right] \mathrm{ACh}$. Similar to calculations typically performed for functional upregulation of dopaminergic function, it is possible to express the upregulation of ACh synthesis by calculating the ratio of ACh synthesis in vivo to a parameter reflecting cholinergic function in vitro. These ratios allow for an estimation of cholinergic synthetic capacity per surviving cholinergic neuron. Our studies revealed that, in the hippocampus ipsilateral to the partial fimbrial lesion, the ratios of $\left[{ }^{2} \mathrm{H}_{4}\right] \mathrm{ACh}$ synthesis in vivo to ChAT activity in homogenates, to $\left[{ }^{3} \mathrm{H}\right] \mathrm{ACh}$ synthesis in slices, and to HACU activity in synaptosomes were increased by $45-75 \%$ over values observed on unlesioned sides (Fig. 3).

\section{Discussion}

This study demonstrates that surviving cholinergic neurons in the hippocampus functionally compensate for partial destruction of the cholinergic septohippocampal pathway. The partial destruction, obtained by partially transecting the fimbria and manifested by a pronounced reduction in cholinergic element density and diminutions in parameters reflecting presynaptic cholinergic function in vitro, did not reduce hippocampal endogenous ACh levels or the in vivo synthetic capacity.

Transection of the lateral fimbria used for partial septohippocampal lesioning results in a gradually increasing loss of cho- 
linergic neurite density along the septotemporal axis of the hippocampus. Limitations in the sensitivity of the methods employed for measuring cholinergic function precluded us from testing for compensation of ACh synthesis as a function of various degrees of cholinergic denervation. All measurements were performed on entire, individual hippocampus, and the data reflect average values in this structure. The in vitro parameters used to assess cholinergic function, ChAT activity in homogenates, $\left[{ }^{3} \mathrm{H}\right] \mathrm{ACh}$ synthesis by hippocampal slices, $\left[{ }^{3} \mathrm{H}\right] \mathrm{ACh}$ release from hippocampal slices, and the activity of the HACU system in synaptosomes were reduced to $35-55 \%$ of control values in partly lesioned hippocampus. Because the tissue was disrupted for these assays, this parameter most likely reflects the maximal capacity of cholinergic terminals to synthesize $\mathrm{ACh}$ from exogenous choline. Given the uniform reductions of in vitro cholinergic parameters, it is justified to assume that the parameters measured reflect the density of residual cholinergic neurons and can serve tentatively as a basis to calculate $\mathrm{ACh}$ synthesis per remaining neuron as shown in Figure 3. According to these calculations, there is a $50-70 \%$ upregulation of $\mathrm{ACh}$ synthesis in cholinergic axons surviving the partial fimbrial transection. The compensatory mechanisms shown to operate in the hippocampus following a partial lesion of its cholinergic input fail to operate after full fimbrial lesions that reduce the levels of presynaptic cholinergic parameters to approximately $20 \%$ of control values. The precise limit of compensation remains to be determined.

The mechanisms involved in the functional upregulation of ACh synthesis by surviving axons remain to be established. Such mechanisms must provide residual cells with information about the status of other cells belonging to the same population. There are several plausible hypotheses: (1) It is possible that following partial fimbrial lesions there is an alteration of autoregulatory mechanisms involved in the synthesis and release of ACh. Presynaptic muscarinic and nicotinic receptors have been shown to be involved in the fine regulation of $\mathrm{ACh}$ release in the hippocampal formation (S7erb et al., 1977; Araujo et al., 1988h; Lapchak et al., $1989 \mathrm{~b}, \mathrm{c})$. Thus, increased activation of nicotinic or decreased activation of muscarinic receptors stimulating $\mathrm{ACh}$ release may allow for a reactive increase in the synthesis of $\mathrm{ACh}$ (i.e., increased tissue content of $\mathrm{ACh}$ ). A prerequisite for such local control of transmitter release is the accessibility of $\mathrm{ACh}$ released from a given terminal to presynaptic receptors on the same terminal and on neighboring terminals. Such a mechanism seems particularly attractive because of its minimum structural requirements. It is supported by observations on the dopaminergic nigrostriatal system, where the removal of polysynaptic inputs and electrical inhibition of cell bodies did not dimish the functional upregulation of dopamine synthesis in the terminal area (F. Hefti and E. Melamed, unpublished observations). However, such a local intrahippocampal compensatory mechanism should also operate in tissue slices and therefore is not supported by our findings. (2) Cholinergic cell bodies could influence each other by axon collaterals in the septum mediating mutually inhibitory influences. Loss of part of the cell population would then reduce the inhibition normally provided by neighboring neurons. (3) Information on the status of the cholinergic system could be mediated by a feedback system involving non-cholinergic neurons. Partial destruction of the cholinergic system could alter the activity of such feedback systems. Any of the listed compensatory mechanisms could result in an increase in the capacity of residual cholinergic terminals to store $\mathrm{ACh}$. This may involve the storage of an increased number of or different pools of vesicles within the terminal. The notion that residual cholinergic terminals compensate by upregulating specific parts of the presynaptic cholinergic machinery is supported by recent observations by Ruberg et al. (1990), which show that the density of binding sites for vesamicol, a compound that specifically labels the ACh uptake carrier protein present on cholinergic vesicles in brain, is not altered by lesions of cholinergic pathways even though the lesion reduced ChAT activity.

The findings indicate that compensatory elevations of transmitter synthesis and release are not a unique feature of catecholaminergic systems and may represent a common regulatory mechanism of many or all neurotransmitter systems. If so, these compensatory changes may be of considerable importance for functional plasticity in the brain after injury and degeneration. Functional compensation at the level of transmitter synthesis and relcasc may occur in parallel with compensatory changes at the morphological level, sprouting and regeneration. In contrast to sprouting and regeneration, which require activation of complex programs of gene expression, functional compensation can be mediated by relatively simple, existing mechanisms resulting in higher energy demand of surviving cells but not involving reprogramming of the pattern of gene expression. As illustrated by the dopaminergic system in Parkinson's disease, functional compensation is able to prevent behavioral manifestions of the gradual loss of cells until only a small percentage of the total population remains. Because basal forebrain cholinergic neurons degenerate in Alzheimer's disease, it seems possible that functional compensation in this system may postpone certain behavioral manifestations.

\section{References}

Abercrombie ED, Zigmond MJ (1989) Partial injury to central noradrenergic neurons: reduction of tissue norepinephrine content is greater than reduction of extracellular norepinephrine measured by microdialysis. J Neurosci 9:4062-4067.

Agid Y, Javoy F, Glowinski J (1973) Hyperactivity of remaining dopaminergic neurons after partial destruction of the nigrostriatal dopaminergic system in the rat. Nature 245:150-151.

Araujo DM, Lapchak PA, Robitaille Y, Gauthier S, Quirion R (1988a) Differential alteration of various cholinergic markers in cortical and sub-cortical regions of the human brain in Alzheimer's disease. J Neurochem 50:1914-1923.

Araujo DM, Lapchak PA, Collier B, Quirion R (1988b) Characterization of $N-\left[{ }^{3} \mathrm{H}\right]$ methylcarbamylcholine binding sites and effect of $\mathrm{N}$-methylcarbamylcholine on acetylcholine release in rat brain. $\mathrm{J}$ Neurochem 51:292-299.

Arendt T, Bigl V, Tennstedt A (1983) Luss of neurons in the nucleus basalis of Meynert in Alzheimer's disease, paralysis agitans and Korsakoff's disease. Acta Neuropathol (Berl) 61:101-108.

Bartus RT, Dean RL, Beer B, Lippa AS (1982) The cholinergic hypothesis of geriatric memory dysfunction. Science 217:408-417.

Bernheimer H, Birkmayer W, Hornykiewicz O (1973) Brain dopamine syndromes of Parkinson and Huntington. J Neurol Sci 20:415-455.

Bowen DM, Smith CB, White P, Davison AN (1976) Neurotransmitter-related enzymes and indices of hypoxia in senile dementia and other abiotrophies. Brain 99:459-496.

Bowen DM, Allen SJ, Benton JS, Goodhart MJ, Haan EA, Palmer AM, Sims NR, Smith CCT, Spillane JA, Esiri MM, Neary D, Snowdon JS, Wilcock GK, Davison AN (1983) Biochemica! assessment of serotonergic and cholinergic dysfunction and cerebral atrophy in Alzheimer's disease. J Neurochem 41:266-272.

Butcher LL, Woolf NJ (1986) Central cholinergic system: synopsis of 
anatomy and overview of physiology and pathology. In: The biolog ical substrates of Alzheimer's disease (Scheiber AB, Wechsler AF, eds), pp 73-86. New York: Academic.

Candy JM, Perry EK, Perry RH, Court JA, Oakley AE, Edwardson JA (1986) The current status of the cortical cholinergic system in Alzheimer's disease and Parkinson's disease. In: Progress in brain research, Vol 70 (Swaab DF, Fliers E, Mirmiram M, Van Gool WA, Van hjaaren F, eds), pp 105-132. London: Elsevier.

Collier B (1988) The synthesis and storage of acetylcholine in mammalian cholinergic nerve terminals. In: Neurotransmitters and cortical function: from molecules to mind (Avoli M, Reader TA, Dykes RW, Gloor P, eds), pp 261-276. New York: Plenum.

Coyle JT, Price DL, de Long MR (1983) Alzheimer's disease: a disease of cortical cholinergic innervation. Science 219:1184-1189.

Cross AJ, Crow TJ, Johnson JA, Perry EK, Perry RH, Blessed G, Tomlinson B (1984) Studies on the neurotransmitter receptor systems in neocortex and hippocampus in senile dementia of the Alzheimer type. J Neurol Sci 64:109-117.

D'Amato RJ, Zweig RM, Whitehouse PJ, Wenk GL, Singer HS, Mayeux Price DL, Snyder SH (1987) Aminergic systems in Alzheimer's disease and Parkinson's disease. Ann Neurol 22:229-236.

Davies P, Maloney AJF (1976) Selective loss of central cholinergic neurons in Alzheimer's disease. Lancet 2:1403.

Francis PT, Palmer AM, Simos NR, Bowen DM, Davison AN, Esiri MM, Neary D (1985) Neurochemical studies of early-onset Alzheimer's disease. Possible influence on treatment. Lancet 4:7-11.

Freeman JJ, Choi RL, Jenden DJ (1981) Plasma choline: its turnover and exchange with brain choline. J Neurochem 24:729-734.

Hefti F, Melamed E, Wurtman RJ (1980) Partial lesions of the rat nigrostriatal system: biochemical characterization. Brain Res 195: 123-137.

Hefti F, David A, Hartikka J (1984) Chronic intraventricular injections of nerve growth factor elevate hippocampal choline acetyltransferase activity in adult rats with partial septo-hippocampal lesions. Brain Res 293:305-311.

Hefti F, Enz A, Melamed E (1985) Partial lesions of the rat nigrostriatal pathway: acceleration of transmitter synthesis and release of surviving dopaminergic neurons by drugs. Neuropharmacology 24:19-23.

Hornykiewicz O (1972) Dopamine and extrapyramidal motor function and dysfunction. Res Publ Assoc Res Nerv Ment Dis 50:390 415.

Jenden DJ, Roch M, Booth RA (1973) Simultaneous measurement of endogenous and deuterium-labeled tracer variants of choline and acetylcholine in subpicomole quantities by gas chromatography/mass spectrometry. Anal Biochem 55:438-448.

Jenden DJ, Choi RL, Silverman RW, Steinborn JA, Roch M, Booth RA (1974) Acetylcholine turnover estimation in brain by gas chromatography/mass spectrometry. Life Sci 14:55-63.

Jope RS (1979) High affinity choline transport and acetyl-CoA production in brain and their roles in the regulation of acetylcholine synthesis. Brain Res Rev 1:313-344.

Kasa P (1986) The cholinergic systems in brain and spinal cord. Prog Neurobiol 26:211-272.

Koenig JFR, Klippel RA (1963) The rat brain. A stereotaxic atlas of the forebrain and lower parts of the brain stem. Baltimore: Williams and Wilkins.

Lapchak PA, Collier B (1988) Vasoactive intestinal peptide increases acetylcholine synthesis by rat hippocampal slices. J Neurochem 50 : 58-64.

Lapchak PA, Hefti F (1991) Effect of recombinant human nerve growth factor on presynaptic function in rat hippocampal slices following partial septo-hippocampal: measures of $\left[{ }^{3} \mathrm{H}\right]$ acetylcholine synthesis, $\left[{ }^{3} \mathrm{H}\right]$ acetylcholine release and choline acetyltransferase activity. Neuroscience 42:639-649.

Lapchak PA, Araujo DM, Quirion R (1989a) Muscarinic and nicotinic receptors in Alzheimer's disease: rationale for cholinergic drug treatment. Adv Behav Biol 36:53-61.
Lapchak PA, Araujo DM, Quirion R, Collier B (1989b) Effect of chronic nicotine treatment on nicotinic autoreceptor function and $\left[{ }^{3} \mathrm{H}\right]$ methylcarbamylcholine binding sites in the rat brain. J Neurochem 52:483-491.

Lapchak PA, Araujo DM, Quirion R, Collier B (1989c) Binding sites for $\left[{ }^{3} \mathrm{H}\right] \mathrm{AF}-\mathrm{DX} 116$ on endogenous acetylcholine release from rat brain slices. Brain Res 486:285-294.

Lapchak PA, Araujo DM, Quirion R, Beaudet A (1991) Immunoautoradiographic localization of interleukin-2-like immunoreactivity and interleukin-2 receptors (Tac antigen-like immunoreactivity) in the rat brain. Neuroscience 44:173-184.

Melamed E, Hefti F, Wurtman RJ (1981) Compensatory mechanisms in nigrostriatal dopaminergic system in Parkinson's disease: studies in an animal model. Isr J Med Sci 18:159-163.

Mesulam MM, Mufson BH, Waincr BH, Levcy AI (1983a) Central cholinergic pathways in the rat: an overview based on an alternative nomenclature (Ch1-Ch6). Neuroscience 10:1185-1201.

Mesulam MM, Mufson EJ, Levey AI, Wainer BH (1983b) Cholinergic innervation of cortex by the basal forebrain: cytochemistry and cortical connections of the septal area, diagonal band nuclei, nucleus basalis (substantia innominata), and hypothalamus in the rhesus monkey. J Comp Neurol 214:170-197.

Montero CN, Hefti F (1988) Rescue of lesioned septal cholinergic neurons by nerve growth factor: specificity and requirement for chronic treatment. J Neurosci 8:2986-2999.

Nagai T, McGeer PL, Peng JH, McGeer EG, Dolman CE (1983) Choline acetyltransferase immunohistochemistry in brains of Alzheimer's disease patients and controls. Neurosci Lett 36:195-199.

Olton DS, Wenk GL (1987) Dementia: animal models of the cognitive impairments produced by degeneration of the basal forebrain cholinergic system. In: Psychopharmacology: the third generation of progress (Meltzer HY, ed), pp 941-953. New York: Raven.

Paxinos G, Watson C (1986) The rat brain in stereotaxic coordinates, $2 \mathrm{~d}$ ed. New York: Academic.

Perry EK, Tomlinson BE, Blessed G, Bergman K, Gibson PH (1978) Correlation of cholinergic abnormalities with senile plaques and mental scores in dementia. Br Med .I 2:1457-1459.

Quirion R, Aubert I, Lapchak PA, Schaum RP, Teolis S, Gauthier S, Araujo DM (1989) Muscarinic receptor subtypes in human neurodegenerative disorders: focus on Alzheimer's disease. Trends Pharmacol Sci [Suppl] 5:80-84.

Ruberg M, Mayo W, Brice A, Duyckaerts C, Hauw JJ, Simon H, LeMoal M, Agid Y (1990) Choline acetyltransferase activity and [ $\left.{ }^{3} \mathrm{H}\right]$ Vesamicol binding in the temporal cortex of patients with Alzheimer's disease, Parkinson's disease, and rats with basal forebrain lesions. Neuroscience 35:327-333.

Stachowiak MK, Keller RJ, Stricker EM, Zigmond MJ (1987) Increased dopamine efflux from striatal slices during development and after nigrostriatal bundle damage. J Neurosci 7:1648-1654.

Szerb JC, Hadhazy P, Dudar JD (1977) Release of [ $\left.{ }^{3} \mathrm{H}\right]$ acetylcholine from rat hippocampal slices: effect of septal lesion and of graded concentrations of muscarinic agonists and antagonists. Brain Res 128: 285-291.

Tago H, Kimura H, Maeda T (1986) Visualization of detailed acetylcholinesterase fiber and neuron staining in rat brain by a sensitive histochemical procedure. J Histochem Cytochem 34:1431-1438.

Whitehouse PJ, Price DL, Struble RG, Clark AW, Coyle JT, De Long MR (1982) Alzheimer's disease and senile dementia; loss of neurons in the basal forebrain. Science 215:1237-1239.

Zigmond MJ, Stricker EM (1989) Animal models of parkinsonism using selective neurotoxins: clinical and basic implication. Int Rev Neurobiol 31:1-79.

Zigmond MJ, Abercrombie ED, Berger TW, Grace AA, Stricker EM (1990) Compensations after lesions of central dopaminergic neurons: some clinical and basic implications. Trends Neurosci 13:290-296. 